\title{
A research on the opinions and suggestions of the youth who study agriculture in Turkey on the Young Farmer Grant Project
}

\author{
Bahar Aydin Can*, Sait Engindeniz**
}

\author{
DOI: $10.30682 / \mathrm{nm} 2004 \mathrm{~h}$ \\ JEL codes: Q10, Q13
}

\begin{abstract}
The agricultural population in Turkey declines year by year due to rural-urban migration and, consequently, the number of young farmers is on the decrease in Turkey, like in some developed countries. The Young Farmer Grant Project was launched for encouraging young people in rural areas in 2016. This study was conducted to determine the tendency of the youth who study agriculture to invest in agriculture and their opinions and suggestions on the Young Farmer Grant Project. Data was collected by the survey from 480 students who studied agriculture at Ege University and Kocaeli University. Five-point Likert scale was used to determine the opinions, tendencies and expectations of the students. At this stage, chi-square tests and analysis of variance were also applied. Logistical regression was performed for determining of factors affecting the probability of students benefiting from the Young Farmer Grant Project. According to results of logistical regression, age, the situation of being a farmer in the family and having a family-owned farmland positively affect the probability of students benefiting from the Young Farmer Grant Project.
\end{abstract}

Keywords: Young farmer grant project support, Agricultural production, Rural development, Youth employment, Students, Turkey.

\section{Introduction}

The Food and Agriculture Organization of the United Nations (FAO) expects the world's population to reach 9 billion in the next 30 years and, in parallel with the population growth, food demand is predicted to increase. However, global warming and decrease in agricultural production, along with the world's increasing population, give the signs of a possible food shortage in the future. In this respect, governments have to produce and develop policies aimed at taking necessary measures to ensure adequate food production.

The young population engaged in agriculture throughout the world is declining every year. For this reason, many countries have started to create various supporting models that can bring young people into agriculture in order to ensure economic sustainability in agricultural production (Yalçın et al., 2020). In most European countries, the number of farmers under the age of 40 is also declining. There is concern that this demographic

\footnotetext{
* Department of Crop and Animal Production, Izmit Vocational School, Kocaeli University, Kartepe, Kocaeli, Turkey.

** Faculty of Agriculture Department of Agricultural Economics, Bornova, Izmir, Turkey.

Corresponding author: baharcan@kocaeli.edu.tr
} 
trend could have a negative impact on the agricultural industry (Leonard et al., 2017).

Agriculture is of distinct importance to developing countries such as Turkey. Because of the supply of raw materials to the industry, exports, qualified labor, employment opportunities, food needs and national income because of its contribution to take on an important task. According to the Turkish Statistical Institute (TurkStat), while the share of agricultural sector in Turkey's Gross Domestic Product (GDP) was 9\% in 2004, it was $6 \%$ in 2018 with $\$ 789$ billion (TurkStat, 2018). For this reason, agriculture needs to be further supported by the state.

The rural population engaged in agricultural production activities is seen to have decreased considerably in Turkey. According to Address-Based Population Registration System data, the proportion of population living in towns and villages was $25 \%$ in 2008 , but decreased to $7.7 \%$ in 2018 (TurkStat, 2019). People migrate from rural to urban areas because the income earned by farmers from agriculture is inadequate for their expenditures, and employment opportunities are available mainly in cities. Additionally, agriculture is not seen as an attractive employment area by young people and the employment potential of non-agricultural sectors in rural areas is low (Kan et al., 2019). As a result, the young population in rural areas wants to live and work in the city and, for this reason, most of the young people in rural areas are not engaged in agriculture. The decline in the number of young farmers, the farmer's reluctance to pass the farm on to new generations, educational, financial and motivational reasons are effective (Corsi, 2009; Mishra et al., 2010; Mishra and El-Osta, 2016; May et al., 2019). The youth's disengagement from, or decreasing interest in, agriculture may result in the loss of productive workforce in a dynamic rural economy model, posing a problem in terms of sustainability (Mosaee and Ommani, 2011). Besides, today's rapid disengagement from agriculture may cause serious problems in food production in the future (Doğan et al., 2015). In rural areas, the young population, which decreases in number, must be directed towards agriculture for economic revival and employment.
The rural population in Turkey is getting older. Young people in rural areas do not see agriculture as an area of work that can improve living conditions (Engindeniz and Can, 2020). The youth migrate from rural to urban areas with the belief that they have no future in the agricultural sector and will have a better social life in the city. Sustainability in agricultural production will only be possible by keeping the young population in agriculture (Doganay and Alim, 2010). However, sustainable rural development and continuity of agricultural production can be achieved only through the youth who have received agricultural education and become specialized in their field (Unakitan and Başaran, 2018).

The Young Farmer Grant Project was introduced to the 18-40-year-old people planning to carry out agricultural activities within the framework of Rural Development Supports to ensure sustainability in agriculture. As part of the project, 14,678 young farmers were granted 450 million Turkish Liras in 2016, and 16,067 young farmers were granted 483 million Turkish Liras in 2017 (TOB, 2013). The increase in the number of applicants indicates that it is possible to increase agricultural employment by supporting young people.

Therefore, it is of great importance for the future that studies are conducted to enhance the opportunities for agricultural employment and rural youth development in agricultural policies both in Turkey and all over the world. In this respect, the young people who have received agricultural education should be guided for economic and social development as well as agricultural sustainability. Thanks to the increase in the incentives and supports provided to the youth who tend to engage in agriculture, directing the youth to agricultural investments has become even more important.

There are many studies on the incentives and supports that have been offered to the youth up to the present in Turkey and all over the world (Aggelopoulos and Arabatzis, 2010; Sottomayor et al., 2011; Harakal'ova, 2013; Harakal'ova, 2014; Derderi et al., 2015; Đurić and Njegovan, 2015; Bournaris et al., 2016; Leonard et al., 2017; Ayele et al., 2017; McKillop et al., 2018; Šimpach, 2017; Walters et al., 2018; Šim- 
pachová Pechrová and Šimpach, 2018; May et al., 2019; Sav and Sayin, 2018; Dogan et al., 2018; Unakitan and Başaran, 2018; Filloux et al., 2019; Salvago et al., 2019; Touzeau, 2019; Brodzinski, 2019; Đurić et al., 2019; Kan et al., 2019; Phiboon et al., 2019; Eistrup et al., 2019; Badan et al., 2019; Cristea et al., 2019; Castillo-Quero and Guerrero-Baena, 2019; May et al., 2019). Nevertheless, there is a need for studies that analyze the tendencies of the youth in Turkey and offer solutions on agricultural incentives and supports.

Agricultural education is a practical education, so it is preferred by students who are more interested. This research was preferred because young people who are interested in agricultural education at the university will have more potential to be interested in agriculture after graduation. Upon graduation, senior students studying agriculture are likely to invest in agricultural production thanks to agricultural supports given to young people. It concerns not only rural youth, but also young people who have studied agriculture, especially in urban areas for keeping and increasing of the young population in agriculture of Turkey. On the other hand, some of the university students are of rural origin and they should be asked whether they want to return to rural areas and deal with agriculture. The opinions and expectations of young people on agricultural supports provided in Turkey is important to prepare the effective and appropriate policies.

This research was conducted to determine the tendency of the youth who study agriculture to invest in agriculture and their opinions and suggestions on the Young Farmer Grant Project. In the scope of the research, a face-to-face survey was conducted on a total of 480 students who studied agriculture at Ege University (EU) and Kocaeli University (KOU).

\section{Materials and Methods}

The primary data obtained from the survey conducted on the seniors who studied agriculture at EU's Faculty of Agriculture and KOU's Arslanbey Agriculture and Food Vocational Schools in the academic year of 2015-2016 constituted the main material of the research. In the survey, the students (seniors) in the last year were interviewed. Seniors were preferred in the research with the idea that seniors have wider knowledge on account of the education they have received and more elaborated forward-looking thoughts because of their upcoming graduation. It was preferred to interview all students without sampling. The data obtained from a total of $480 \mathrm{stu}-$ dents (176 undergraduate degree students from EU and 304 associate degree students from KOU) was evaluated. The survey was conducted in April and May of 2016. The questionnaires were filled by the students between the courses at the universities.

The survey form used in the research is composed of two main sections. The first section contains questions about the students' demographic characteristics, while the second section is made up of questions to express their tendency to invest in agriculture and opinions and suggestions on the Young Farmer Grant Project.

The data collected through the survey was encoded and interpreted on the SPSS 22.0. Frequency and \% distributions, chi-square test and analysis of variance were employed to analyze the data. 5-point Likert scale was used for presenting the students' opinions, tendencies and expectations on the Young Farmer Grant Project.

In this study, logistical regression (logit model) was performed for determining of factors affecting the probability of students benefiting from the Young Farmer Grant Project. When the dependent variable is a $0-1$ binary variable, the logit or probit model estimation methods can be used. The logit model has the following functional form (Greene, 1993; Gujarati, 1995; Ramanathan, 1995):

$$
P_{i}=E\left(Y=1 / X_{1}\right)=\frac{1}{1+e^{-\left(z_{i}\right)}}=\frac{1}{1+e^{-\left(\beta_{1}+\beta_{2} X_{i}\right)}}
$$

In the equation:

$\mathrm{P}=$ the probability of choosing

$\mathrm{E}=$ cumulative probability function

$z=\alpha+\beta X_{i}$

$\alpha=$ constant coefficient

$\beta=$ parameter to be estimated for each descriptive (independent) variable

$X=$ independent variable 
In the logit model, the dependent variable $(Y)$ is student's willingness to benefit from the Young Farmer Grant Project. If students want to benefit from the Young Farmer Grant Project, the dependent variable takes the value 1, and 0 otherwise. $i$ is a vector of explanatory variables related to student's benefit from the Young Farmer Grant Project and $\beta$ is the vector of estimated coefficients. Positive coefficients increase the probability that a student benefit from the Young Farmer Grant Project. For the logit model, the most suitable estimation technique is maximum likelihood, where the maximum likelihood coefficient is consistent and symptotically normally distributed (Bierens, 2004).

\section{Results}

\subsection{Students' demographic and socio- economic characteristics}

In this section, research findings were evaluated statistically. The students who took part in the survey were analyzed first in terms of their demographic characteristics. As is seen from Table 1, $51.66 \%$ of the students were female, and $48.34 \%$ were male. At EU, 37.50\% were female, and $62.50 \%$ were male. At KOU, however, $59.86 \%$ were female, and $40.14 \%$ were male. Of all the students, 93.95\% were single, while $6.05 \%$ were married. The number of married students was higher at Kocaeli Uni-

Table 1 - Students' demographic characteristics.

\begin{tabular}{|c|c|c|c|c|c|c|}
\hline \multirow{2}{*}{$\begin{array}{ll} & \text { Characteristics } \\
\text { Sex }\end{array}$} & \multicolumn{2}{|c|}{ Ege University } & \multicolumn{2}{|c|}{ Kocaeli University } & \multicolumn{2}{|l|}{ Total } \\
\hline & Number & $\%$ & Number & $\%$ & Number & $\%$ \\
\hline Female & 66 & 37.50 & 182 & 59.86 & 248 & 51.66 \\
\hline Male & 110 & 62.50 & 122 & 40.14 & 232 & 48.34 \\
\hline Total & 176 & 100.00 & 304 & 100.0 & 480 & 100.00 \\
\hline \multicolumn{7}{|l|}{ Age Group } \\
\hline $19-21$ & 10 & 5.68 & 204 & 67.11 & 214 & 44.58 \\
\hline $22-24$ & 129 & 73.30 & 67 & 22.04 & 196 & 40.84 \\
\hline 25 years old and older & 37 & 21.02 & 33 & 10.85 & 70 & 14.58 \\
\hline Total & 176 & 100.00 & 304 & 100.00 & 480 & 100.00 \\
\hline \multicolumn{7}{|l|}{ Marital Status } \\
\hline Married & 4 & 2.27 & 25 & 8.22 & 29 & 6.05 \\
\hline Single & 172 & 97.73 & 279 & 91.78 & 451 & 93.95 \\
\hline Total & 176 & 100.00 & 304 & 100.00 & 480 & 100.00 \\
\hline \multicolumn{7}{|l|}{ Monthly Family Income } \\
\hline $1000 \mathrm{TRY}$ and below & 18 & 10.23 & 43 & 14.15 & 19 & 3.95 \\
\hline 1001-1500 TRY & 29 & 16.47 & 79 & 25.98 & 108 & 22.50 \\
\hline 1500-2000 TRY & 18 & 10.23 & 35 & 11.52 & 53 & 11.04 \\
\hline 2000-2500 TRY & 24 & 13.64 & 56 & 18.42 & 80 & 16.67 \\
\hline 2501-3000 TRY & 18 & 10.23 & 26 & 8.55 & 44 & 9.17 \\
\hline $3000 \mathrm{TRY}$ and above & 69 & 39.20 & 65 & 21.38 & 134 & 27.91 \\
\hline Total & 176 & 100.00 & 304 & 100.00 & 480 & 100.00 \\
\hline \multicolumn{7}{|l|}{ Place of Birth } \\
\hline Province center & 100 & 56.82 & 121 & 39.80 & 221 & 46.04 \\
\hline District center & 58 & 32.96 & 122 & 40.13 & 180 & 37.50 \\
\hline Town & 3 & 1.70 & 33 & 10.86 & 36 & 7.50 \\
\hline Village & 15 & 8.52 & 28 & 9.21 & 43 & 8.96 \\
\hline Total & 176 & 100.00 & 304 & 100.00 & 480 & 100.00 \\
\hline
\end{tabular}


versity, with a share of $8.22 \%$. In terms of their monthly family income, the students who had a monthly family income of 3000 TRY and above had the highest proportion (27.91\%) both at EU and at KOU.

$45 \%$ of the students stated that they had been working, while $55 \%$ stated they had not. Of all students who had been working, those between the ages of 19 and 21 had the highest proportion (43.52\%). The students of both EU and $\mathrm{KOU}$ were asked to define their economic condition, and 173 said "I can only afford the basic needs" (36.04\%), 115 said "I can buy most of what I want" (23.96\%), and 105 said "I live in prosperity" (21.87\%), respectively. 37 students said "I cannot afford the basic needs", with the lowest share of $7.71 \%$. In general, the majority of students had a level of income to afford the basic needs and buy most of what they wanted.

\subsection{Students' opinion on investing in agriculture}

The agricultural students were asked to sort their expectations from investing in agriculture by level of importance. Table 2 shows the findings obtained. For evaluation purposes, attitude sentences were scored as 1- Not at all important, 2- Slightly important, 3- Neutral, 4- Important, 5- Extremely important and weighted averages were calculated. The greatest expectation of the students from investing in agriculture was "enhancing employment opportunities", with an average score of 4.40 , followed by "adjusting production to natural conditions" with an average score of 4.37 and "implementing agricultural innovations" with an average score of 4.35 . These findings suggest that the students are more willing to invest in the agricultural fields that provide employment

Table 2 - Students' expectations from investing in agriculture.

\begin{tabular}{|c|c|c|c|c|c|c|c|c|}
\hline Expectations & $\begin{array}{l}1 \\
N \\
\% \\
\end{array}$ & $\begin{array}{l}2 \\
N \\
\% \\
\end{array}$ & $\begin{array}{c}3 \\
N \\
\% \\
\end{array}$ & $\begin{array}{c}4 \\
N \\
\% \\
\end{array}$ & $\begin{array}{l}5 \\
N \\
\% \\
\end{array}$ & $\begin{array}{c}T N \\
\%\end{array}$ & Avg. & $S S$ \\
\hline Earning money & $\begin{array}{c}9 \\
1.9\end{array}$ & $\begin{array}{l}30 \\
6.3\end{array}$ & $\begin{array}{l}35 \\
7.3\end{array}$ & $\begin{array}{l}207 \\
43.1\end{array}$ & $\begin{array}{r}199 \\
41.4\end{array}$ & $\begin{array}{c}480 \\
100.0\end{array}$ & 2.79 & 1.61 \\
\hline Motivation and working & $\begin{array}{c}8 \\
1.7\end{array}$ & $\begin{array}{l}15 \\
3.1\end{array}$ & $\begin{array}{l}44 \\
9.2\end{array}$ & $\begin{array}{l}228 \\
47.5\end{array}$ & $\begin{array}{l}185 \\
38.5\end{array}$ & $\begin{array}{c}480 \\
100.0\end{array}$ & 2.97 & 1.61 \\
\hline Self-fulfillment & $\begin{array}{l}10 \\
2.1\end{array}$ & $\begin{array}{l}23 \\
4.8\end{array}$ & $\begin{array}{l}47 \\
9.1\end{array}$ & $\begin{array}{l}200 \\
41.7\end{array}$ & $\begin{array}{l}200 \\
41.7\end{array}$ & $\begin{array}{c}480 \\
100.0\end{array}$ & 2.72 & 1.59 \\
\hline $\begin{array}{l}\text { Making use of the knowledge of } \\
\text { agriculture }\end{array}$ & $\begin{array}{c}6 \\
1.3\end{array}$ & $\begin{array}{l}14 \\
2.9\end{array}$ & $\begin{array}{l}31 \\
6.4\end{array}$ & $\begin{array}{l}246 \\
51.3\end{array}$ & $\begin{array}{r}183 \\
38.1\end{array}$ & $\begin{array}{c}480 \\
100.0\end{array}$ & 3.62 & 1.26 \\
\hline Contributing to national agriculture & $\begin{array}{c}2 \\
0.4\end{array}$ & $\begin{array}{l}25 \\
5.3\end{array}$ & $\begin{array}{l}31 \\
6.4\end{array}$ & $\begin{array}{l}213 \\
44.4\end{array}$ & $\begin{array}{l}209 \\
43.5\end{array}$ & $\begin{array}{c}480 \\
100.0\end{array}$ & 3.52 & 1.02 \\
\hline Offering natural food to consumers & $\begin{array}{c}4 \\
0.8\end{array}$ & $\begin{array}{l}22 \\
4.6\end{array}$ & $\begin{array}{c}36 \\
7.6\end{array}$ & $\begin{array}{l}197 \\
41.0\end{array}$ & $\begin{array}{l}221 \\
46.0\end{array}$ & $\begin{array}{c}480 \\
100.0\end{array}$ & 3.18 & 1.54 \\
\hline $\begin{array}{l}\text { Making the best of agricultural } \\
\text { production factors }\end{array}$ & $\begin{array}{c}6 \\
1.3\end{array}$ & $\begin{array}{c}9 \\
1.9\end{array}$ & $\begin{array}{l}41 \\
8.5\end{array}$ & $\begin{array}{l}198 \\
41.2\end{array}$ & $\begin{array}{l}226 \\
47.1\end{array}$ & $\begin{array}{c}480 \\
100.0\end{array}$ & 3.25 & 1.48 \\
\hline Enhancing employment opportunities & $\begin{array}{l}10 \\
2.1\end{array}$ & $\begin{array}{l}21 \\
4.4\end{array}$ & $\begin{array}{c}50 \\
10.4\end{array}$ & $\begin{array}{l}204 \\
42.5\end{array}$ & $\begin{array}{l}195 \\
40.6\end{array}$ & $\begin{array}{c}480 \\
100.0\end{array}$ & 4.40 & 0.84 \\
\hline Implementing agricultural innovations & $\begin{array}{c}2 \\
0.4\end{array}$ & $\begin{array}{c}9 \\
1.9\end{array}$ & $\begin{array}{l}23 \\
4.8\end{array}$ & $\begin{array}{l}211 \\
43.9\end{array}$ & $\begin{array}{l}235 \\
49.0\end{array}$ & $\begin{array}{c}480 \\
100.0\end{array}$ & 4.35 & 0.73 \\
\hline $\begin{array}{l}\text { Adjusting production to natural } \\
\text { conditions }\end{array}$ & $\begin{array}{l}11 \\
2.3\end{array}$ & $\begin{array}{l}20 \\
4.2\end{array}$ & $\begin{array}{l}25 \\
5.2\end{array}$ & $\begin{array}{c}191 \\
39.8\end{array}$ & $\begin{array}{l}233 \\
48.5\end{array}$ & $\begin{array}{c}480 \\
100.0\end{array}$ & 4.37 & 0.76 \\
\hline
\end{tabular}

Note: Scale values 1 - Not at all important; 2 - Slightly important; 3 - Neutral; 4 - Important; 5 - Extremely important. 
opportunities and enable them to employ hightech tools in agriculture in line with the education they have undergone.

The students were asked how to convert this money into investment if you own 30,000 TRY. The most popular response was "I would start my own business", given by 207 students. This response was followed by "I would deposit it in a bank" (91 students) and "I would play on the stock market" (87 students), respectively. The analysis of variance conducted proves that there is a significant difference between the students' opinion on turning 30,000 TRY into an investment and their sex $(p=0.020<0.05)$, while no significant difference between their opinion and age $(\mathrm{p}=0.468>0.05)$.

\subsection{Students' opinions and expectations on the young farmer grant project}

For the purpose of determining the agricultural students' opinions on, and expectations from, the Young Farmer Grant Project, they were first asked from which source they had heard about the Project. The top response was "TV-Radio", given by 235 students. The next two responses were "Internet" (199 students) and "friends" (185 students), respectively. The fact that the most popular response given by the students of both EU and KOU was "TV-Radio" suggests the students actively listen to the radio and use the Internet and social media from their mobile phones.

A chi-square analysis was conducted to determine the relationship between the students' sex and their level of awareness of the Young Farmer Grant Project, and the difference between the variables was found significant $(p=0.026<0.05)$, as is seen from Table 3. In the case of female students, those who were "slightly aware" (67 female students) had the highest proportion $(27.13 \%)$. On the other hand, the highest proportion $(31.33 \%)$ in the case of male students belonged to those who were "moderately aware" (73 male students). It is thought that, compared to female students, male students are more aware of, and more interested in, the Young Farmer Grant Project. Dogan et al. carried out a study in 2018 in the TR 71 Region of Turkey (provinces of Aksaray, Kirikkale, Kirsehir, Nevsehir, and Nigde) and found that $63.3 \%$ of the people who benefited from the Young Farmer Grant Project were male. Their finding supports the thought mentioned above.

The likelihood of the students to make use of the Young Farmer Grant Project was analyzed

Table 3 - Relationship between the students' sex and their level of awareness of the young farmer grant project.

\begin{tabular}{|c|c|c|c|c|c|c|c|}
\hline \multirow{2}{*}{\multicolumn{2}{|c|}{ Level of Awareness }} & \multicolumn{2}{|c|}{ Sex } & \multirow{2}{*}{ Total } & \multicolumn{3}{|c|}{ Chi-Square Test Result } \\
\hline & & Female & Male & & $\chi^{2}$ & $s d$ & $P^{*}$ \\
\hline \multirow[t]{2}{*}{ Not at all aware } & $\mathrm{n}$ & 30 & 23 & 53 & \multirow{12}{*}{11.068} & \multirow{12}{*}{4} & \multirow{12}{*}{0.026} \\
\hline & $\%$ & 12.14 & 9.87 & 11.04 & & & \\
\hline \multirow[t]{2}{*}{ Slightly aware } & $\mathrm{n}$ & 67 & 38 & 105 & & & \\
\hline & $\%$ & 27.13 & 16.31 & 21.88 & & & \\
\hline \multirow[t]{2}{*}{ Somewhat aware } & $\mathrm{n}$ & 44 & 42 & 86 & & & \\
\hline & $\%$ & 17.81 & 18.03 & 17.91 & & & \\
\hline \multirow[t]{2}{*}{ Moderately aware } & $\mathrm{n}$ & 61 & 73 & 134 & & & \\
\hline & $\%$ & 24.70 & 31.33 & 27.92 & & & \\
\hline \multirow[t]{2}{*}{ Extremely aware } & $\mathrm{n}$ & 45 & 57 & 102 & & & \\
\hline & $\%$ & 18.22 & 24.46 & 21.25 & & & \\
\hline \multirow[t]{2}{*}{ Total } & $\mathrm{n}$ & 247 & 233 & 480 & & & \\
\hline & $\%$ & 100.00 & 100.00 & 100.00 & & & \\
\hline
\end{tabular}

Note: *It is significant at the 0.05 level. 
by age groups. As is seen from Table 4, of all 348 students "likely" and "extremely likely" to make use of the support, 157 were 22-24 years old, with the highest share. As a result of the chi-square analysis, the relationship between the students' age group and their likelihood to make use of the Young Farmer Grant Project was found to be significant $(\mathrm{p}=0.003<0.05)$.
Of all EU and KOU students taking part in the research, 205 had a family-owned farmland, while 275 did not. Besides, $26.5 \%$ of the students had at least one family member engaged in farming. This proportion was $29.5 \%$ for $\mathrm{KOU}$ students, and $21 \%$ for EU students. As is seen from Table 5, 355 students (73.96\%) stated they did not plan to live in the rural area to

Table 4 - Relationship between the students' age group and their likelihood to make use of the young farmer grant.

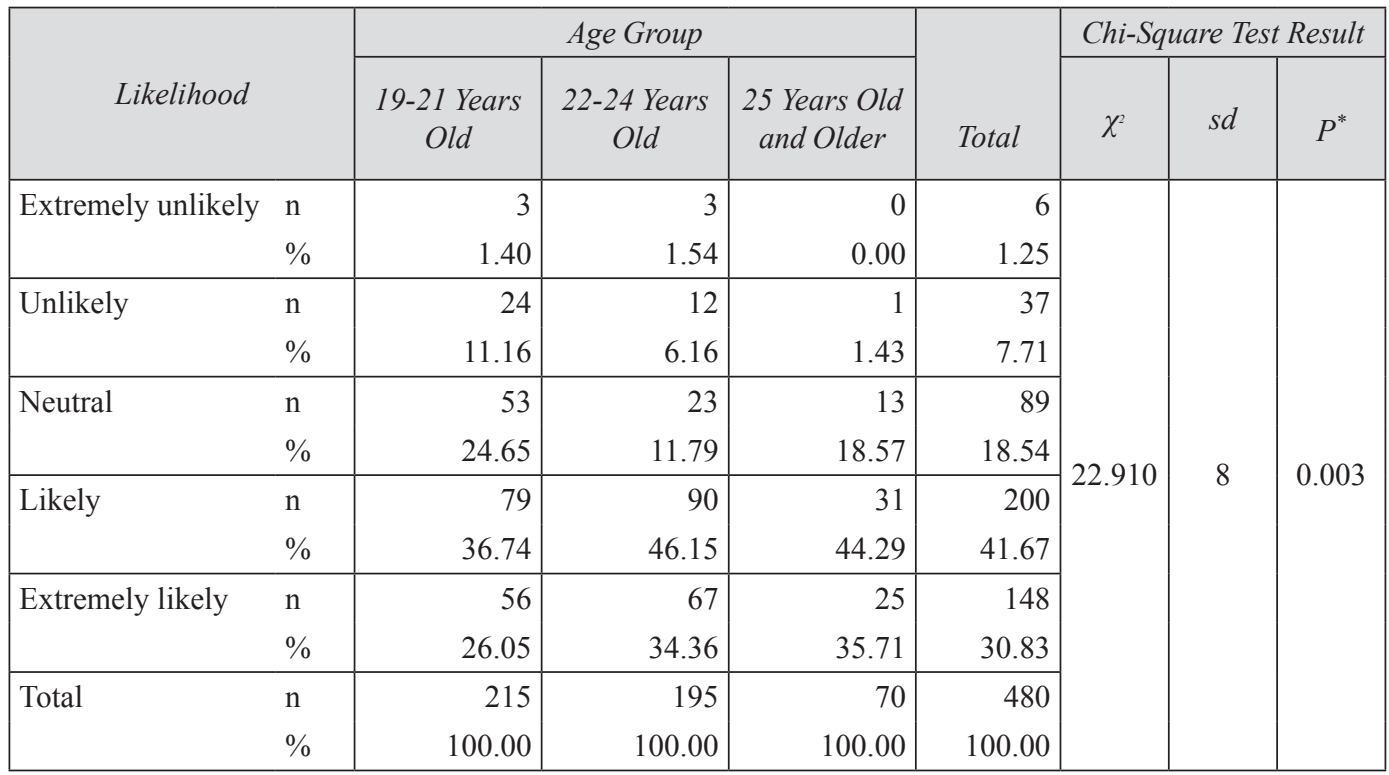

Note: *It is significant at the 0.05 level.

Table 5 - Students' plan on living in the rural area to make use of the young farmer grant project by having a family-owned farmland.

\begin{tabular}{|c|c|c|c|c|c|c|c|c|c|c|}
\hline \multirow{3}{*}{$\begin{array}{c}\text { Plan on } \\
\text { living in } \\
\text { the rural } \\
\text { area }\end{array}$} & \multicolumn{4}{|c|}{ Ege University } & \multicolumn{4}{|c|}{ Kocaeli University } & \multirow{2}{*}{\multicolumn{2}{|c|}{ Total }} \\
\hline & \multicolumn{2}{|c|}{$\begin{array}{l}\text { Has a family- } \\
\text { owned farmland }\end{array}$} & \multicolumn{2}{|c|}{$\begin{array}{l}\text { Does not have } \\
\text { a family-owned } \\
\text { farmland }\end{array}$} & \multicolumn{2}{|c|}{$\begin{array}{l}\text { Has a family- } \\
\text { owned farmland }\end{array}$} & \multicolumn{2}{|c|}{$\begin{array}{l}\text { Does not have } \\
\text { a family-owned } \\
\text { farmland }\end{array}$} & & \\
\hline & Number & $\%$ & Number & $\%$ & Number & $\%$ & Number & $\%$ & Number & $\%$ \\
\hline $\begin{array}{l}\text { Plans to } \\
\text { live in } \\
\text { the rural } \\
\text { area }\end{array}$ & 8 & 21.62 & 20 & 14.39 & 62 & 45.59 & 35 & 20.83 & 125 & 26.04 \\
\hline $\begin{array}{l}\text { Does not } \\
\text { plan to } \\
\text { live in } \\
\text { the rural } \\
\text { area } \\
\end{array}$ & 29 & 78.38 & 119 & 85.61 & 74 & 54.41 & 133 & 79.17 & 355 & 73.96 \\
\hline $\begin{array}{l}\text { Grand } \\
\text { Total }\end{array}$ & 37 & 100.00 & 139 & 100.00 & 136 & 100.00 & 168 & 100.00 & 480 & 100.00 \\
\hline
\end{tabular}


make use of the Young Farmer Grant Project, suggesting that having a family-owned farmland does not have that much effect on such a plan.

A chi-square analysis was performed to assess the relationship between the students' family income and finding themselves qualified for investing in agriculture, and the relationship was found significant $(p=0.001<0.05)$, as is seen from Table 6. Of the students "extremely likely" to invest in agriculture, those with a family income of 3000 TRY and above had the highest proportion (46.51\%). On the other hand, of the students having a family income of 1000 TRY and below, those "extremely unlikely" to invest in agriculture had the highest proportion, with a share of $39.22 \%$. These findings indicate that the students who have a lower level of income are less courageous in making investments, while those having a higher level of income are more courageous because they are economically better off.

The students were asked their opinion on the changes that the Young Farmer Grant Project, which was launched in Turkey in 2016, could lead to in the future. The change expected most was "The number of young people engaged in agriculture will increase" (254 students), followed by "Engaging in agriculture will become an important profession" (225 students) and "Rural-urban migration will decrease" (222 students), respectively (Table 7). So, for the students, the Young Farmer Grant Project will contribute to the development of agriculture in the future.

Students' opinion was examined on the likelihood of the 18-41-year-old people's taking advantage of the young farmer grant project. $48.54 \%$ of the students (233 students) said 18-41-year-old people were "extremely likely" to take advantage of the Young Farmer Grant Project, and $29.79 \%$ expressed it was "likely". The analysis of variance demonstrated that there was a significant difference between the students' opinion on the likelihood of the 18-41-year-old people's taking advantage of the Project and their sex $(\mathrm{p}=0.043<0.0059)$ and age $(p=0.037<0.05) .48 .5 \%$ of the female students and $51.5 \%$ of the male students said $18-41$-year-

Table 6 - Relationship between the students' family income and finding themselves qualified for investing in agriculture.

\begin{tabular}{|c|c|c|c|c|c|c|c|c|c|c|c|c|c|c|c|}
\hline \multirow{3}{*}{$\begin{array}{l}\text { Family } \\
\text { Income }\end{array}$} & \multicolumn{10}{|c|}{ Likelihood of Investing in Agriculture } & \multirow{2}{*}{\multicolumn{2}{|c|}{ Total }} & \multirow{2}{*}{\multicolumn{3}{|c|}{$\begin{array}{c}\text { Chi-Square Test } \\
\text { Result }\end{array}$}} \\
\hline & \multicolumn{2}{|c|}{$\begin{array}{l}\text { Extremely } \\
\text { Unlikely }\end{array}$} & \multicolumn{2}{|c|}{ Unlikely } & \multicolumn{2}{|c|}{ Neutral } & \multicolumn{2}{|c|}{ Likely } & \multicolumn{2}{|c|}{$\begin{array}{l}\text { Extremely } \\
\text { Likely }\end{array}$} & & & & & \\
\hline & $N$ & $\%$ & $N$ & $\%$ & $N$ & $\%$ & $N$ & $\%$ & $N$ & $\%$ & $N$ & $\%$ & $K 2$ & $d_{f}$ & $P^{*}$ \\
\hline $\begin{array}{l}1000 \\
\text { TRY and } \\
\text { below }\end{array}$ & 80 & 39.22 & 21 & 32.81 & 16 & 20.25 & 18 & 20.00 & 10 & 23.26 & 145 & 30.21 & & & \\
\hline $\begin{array}{l}1001-1500 \\
\text { TRY }\end{array}$ & 23 & 11.27 & 13 & 20.31 & 17 & 21.52 & 22 & 24.44 & 5 & 11.63 & 80 & 16.67 & & & \\
\hline $\begin{array}{l}1501-2000 \\
\text { TRY }\end{array}$ & 8 & 3.92 & 9 & 14.06 & 12 & 15.19 & 8 & 8.89 & 3 & 6.98 & 40 & 8.33 & & & \\
\hline $\begin{array}{l}2001-2500 \\
\text { TRY }\end{array}$ & 29 & 14.22 & 6 & 9.38 & 14 & 17.72 & 13 & 14.44 & 3 & 6.98 & 65 & 13.54 & 53.391 & 24 & 0.001 \\
\hline $\begin{array}{l}2501-3000 \\
\text { TRY }\end{array}$ & 7 & 3.43 & 4 & 6.25 & 1 & 1.27 & 6 & 6.67 & 2 & 4.65 & 20 & 4.17 & & & \\
\hline $\begin{array}{l}3000 \\
\text { TRY and } \\
\text { above }\end{array}$ & 57 & 27.94 & 11 & 17.19 & 19 & 24.05 & 23 & 25.56 & 20 & 46.51 & 130 & 27.08 & & & \\
\hline Total & 204 & 100.00 & 64 & 100.00 & 79 & 100.00 & 90 & 100.00 & 43 & 100.00 & 480 & 100.00 & & & \\
\hline
\end{tabular}

Note: *It is significant at the 0.05 level. 
Table 7 - Students' predictions of the future effects of the young farmer grant project by sex.

\begin{tabular}{|c|c|c|c|c|c|c|c|}
\hline \multirow{2}{*}{ Prediction } & \multirow[b]{2}{*}{ Sex } & \multicolumn{2}{|c|}{ Ege University } & \multicolumn{2}{|c|}{ Kocaeli University } & \multicolumn{2}{|c|}{ Total } \\
\hline & & Number & $\%$ & Number & $\%$ & Number & $\%$ \\
\hline \multirow{2}{*}{$\begin{array}{l}\text { Rural-urban migration } \\
\text { will decrease }\end{array}$} & Female & 32 & 34.04 & 77 & 60.16 & 109 & 49.10 \\
\hline & Male & 62 & 65.96 & 51 & 39.84 & 113 & 50.90 \\
\hline \multicolumn{2}{|l|}{ Total } & 94 & 100.00 & 128 & 100.00 & 222 & 100.00 \\
\hline \multirow{2}{*}{$\begin{array}{l}\text { Farmlands will increase } \\
\text { in value }\end{array}$} & Female & 24 & 33.33 & 78 & 55.71 & 102 & 48.11 \\
\hline & Male & 48 & 66.67 & 62 & 44.29 & 110 & 51.89 \\
\hline \multicolumn{2}{|l|}{ Total } & 72 & 100.00 & 140 & 100.00 & 212 & 100.00 \\
\hline \multirow{2}{*}{$\begin{array}{l}\text { The number of young } \\
\text { people engaged in } \\
\text { agriculture will increase }\end{array}$} & Female & 25 & 33.78 & 108 & 60.00 & 133 & 52.36 \\
\hline & Male & 49 & 66.22 & 72 & 40.00 & 121 & 47.64 \\
\hline \multicolumn{2}{|l|}{ Total } & 74 & 100.00 & 180 & 100.00 & 254 & 100.00 \\
\hline \multirow{2}{*}{$\begin{array}{l}\text { Engaging in agriculture } \\
\text { will become an } \\
\text { important profession }\end{array}$} & Female & 34 & 41.46 & 81 & 56.64 & 115 & 51.11 \\
\hline & Male & 48 & 58.54 & 62 & 43.36 & 110 & 48.89 \\
\hline \multicolumn{2}{|l|}{ Total } & 82 & 100.00 & 143 & 100.00 & 225 & 100.00 \\
\hline \multirow{2}{*}{$\begin{array}{l}\text { National agricultural } \\
\text { production will grow }\end{array}$} & Female & 26 & 33.77 & 82 & 54.67 & 108 & 47.58 \\
\hline & Male & 51 & 66.23 & 68 & 45.33 & 119 & 52.42 \\
\hline \multicolumn{2}{|l|}{ Total } & 77 & 100.00 & 150 & 100.00 & 227 & 100.00 \\
\hline \multirow{2}{*}{ Other } & Female & 3 & 33.33 & 4 & 23.53 & 7 & 26.92 \\
\hline & Male & 6 & 66.67 & 13 & 76.47 & 19 & 73.08 \\
\hline \multicolumn{2}{|l|}{ Total } & 9 & 100.00 & 17 & 100.00 & 26 & 100.00 \\
\hline
\end{tabular}

old people were "extremely likely" to take advantage of the Young Farmer Grant Project. The students indicated that the Young Farmer Grant Project could be an opportunity especially for young entrepreneurs.

The relationship between the students' family income and finding 30,000 TRY given as the Young Farmer Grant adequate was assessed. The amount of grant in question was found inadequate by 346 students and adequate by 134 students. Of the students who found the amount adequate, those with a family income of 1000 TRY and below had the highest proportion $(25.37 \%)$. Likewise, of the students who found the amount inadequate, those with a family income of 1000 TRY and below again had the highest proportion (32.08\%). As a result of the chi-square analysis, the relationship between the students' family income and find- ing 30,000 TRY given as the Young Farmer Grant adequate was found to be insignificant $(p=0.176>0.05)$.

The students were asked their opinion on the level of importance of the project subjects supported within the scope of the Young Farmer Grant Project for Turkey's rural development (Table 8). For evaluation purposes, attitude sentences were scored as 1 - Not at all important, 2 Slightly important, 3 - Neutral, 4 - Important, 5 - Extremely important, and weighted averages were calculated. As is seen from Table 8, the project subject to which the students attributed the highest importance for Turkey's rural development was "plant and animal production with organic and good agriculture practices" with an average score of 4.28 , followed by "producing, processing and packaging food with geographical indication" with an average score of 4.11 
Table 8 - Distribution of the young farmer grant project subjects by level of importance for Turkey's rural development.

\begin{tabular}{|c|c|c|c|c|c|c|c|c|}
\hline Project Subjects & $\begin{array}{l} \\
N \\
\%\end{array}$ & $\begin{array}{c}2 \\
N \\
\%\end{array}$ & $\begin{array}{c}3 \\
N \\
\%\end{array}$ & $\begin{array}{l}4 \\
N \\
\%\end{array}$ & $\begin{array}{l}5 \\
N \\
\%\end{array}$ & $\begin{array}{c}T N \\
\%\end{array}$ & Avg. & SS \\
\hline Cattle breeding & $\begin{array}{r}180 \\
37.4\end{array}$ & $\begin{array}{r}41 \\
8.5\end{array}$ & $\begin{array}{r}49 \\
10.2\end{array}$ & $\begin{array}{r}107 \\
22.2\end{array}$ & $\begin{array}{r}103 \\
21.4\end{array}$ & $\begin{array}{r}480 \\
100.0\end{array}$ & 2.81 & 1.62 \\
\hline Sheep and goat breeding & $\begin{array}{r}76 \\
15.8\end{array}$ & $\begin{array}{r}98 \\
20.4\end{array}$ & $\begin{array}{r}72 \\
15.0\end{array}$ & $\begin{array}{r}110 \\
22.9\end{array}$ & $\begin{array}{r}124 \\
25.8\end{array}$ & $\begin{array}{r}480 \\
100.0\end{array}$ & 3.22 & 1.43 \\
\hline Beekeeping & $\begin{array}{r}72 \\
15.0\end{array}$ & $\begin{array}{r}67 \\
13.9\end{array}$ & $\begin{array}{r}89 \\
18.5\end{array}$ & $\begin{array}{r}127 \\
26.4\end{array}$ & $\begin{array}{r}125 \\
26.0\end{array}$ & $\begin{array}{r}480 \\
100.0\end{array}$ & 3.34 & 1.38 \\
\hline Poultry farming & $\begin{array}{r}11 \\
2.3\end{array}$ & $\begin{array}{l}44 \\
9.1\end{array}$ & $\begin{array}{r}127 \\
26.4\end{array}$ & $\begin{array}{r}177 \\
36.8\end{array}$ & $\begin{array}{r}121 \\
25.2\end{array}$ & $\begin{array}{r}480 \\
100.0\end{array}$ & 3.73 & 1.01 \\
\hline Silkworm breeding & $\begin{array}{r}17 \\
3.5\end{array}$ & $\begin{array}{r}53 \\
11.0\end{array}$ & $\begin{array}{r}121 \\
25.2\end{array}$ & $\begin{array}{r}161 \\
33.5\end{array}$ & $\begin{array}{r}128 \\
26.6\end{array}$ & $\begin{array}{r}480 \\
100.0\end{array}$ & 3.68 & 1.09 \\
\hline Orcharding & $\begin{array}{r}19 \\
4.0\end{array}$ & $\begin{array}{r}40 \\
8.3\end{array}$ & $\begin{array}{r}75 \\
15.6\end{array}$ & $\begin{array}{r}182 \\
37.8\end{array}$ & $\begin{array}{r}164 \\
34.1\end{array}$ & $\begin{array}{r}480 \\
100.0\end{array}$ & 3.90 & 1.08 \\
\hline Viticulture & $\begin{array}{r}21 \\
4.4\end{array}$ & $\begin{array}{r}21 \\
4.4\end{array}$ & $\begin{array}{r}71 \\
14.8\end{array}$ & $\begin{array}{r}193 \\
40.1\end{array}$ & $\begin{array}{r}174 \\
36.2\end{array}$ & $\begin{array}{r}480 \\
100.0\end{array}$ & 3.99 & 1.03 \\
\hline $\begin{array}{l}\text { Orcharding for strawberry and other } \\
\text { berry fruits }\end{array}$ & $\begin{array}{r}24 \\
5.0\end{array}$ & $\begin{array}{l}29 \\
6.0\end{array}$ & $\begin{array}{r}87 \\
18.1\end{array}$ & $\begin{array}{r}194 \\
40.3\end{array}$ & $\begin{array}{r}146 \\
30.4\end{array}$ & $\begin{array}{r}480 \\
100.0\end{array}$ & 3.85 & 1.07 \\
\hline Mushroom cultivation & $\begin{array}{r}27 \\
5.6\end{array}$ & $\begin{array}{l}40 \\
8.3\end{array}$ & $\begin{array}{r}125 \\
26.0\end{array}$ & $\begin{array}{r}141 \\
39.3\end{array}$ & $\begin{array}{r}147 \\
30.6\end{array}$ & $\begin{array}{r}480 \\
100.0\end{array}$ & 3.71 & 1.15 \\
\hline $\begin{array}{l}\text { Producing, processing and packaging } \\
\text { medicinal and aromatic plants }\end{array}$ & $\begin{array}{r}17 \\
3.5\end{array}$ & $\begin{array}{r}35 \\
7.3\end{array}$ & $\begin{array}{r}87 \\
18.1\end{array}$ & $\begin{array}{r}140 \\
29.1\end{array}$ & $\begin{array}{r}201 \\
41.8\end{array}$ & $\begin{array}{r}480 \\
100.0\end{array}$ & 3.98 & 1.10 \\
\hline $\begin{array}{l}\text { Plant and animal production with } \\
\text { organic and good agriculture practices }\end{array}$ & $\begin{array}{r}16 \\
3.3\end{array}$ & $\begin{array}{r}19 \\
4.0\end{array}$ & $\begin{array}{r}42 \\
8.7\end{array}$ & $\begin{array}{r}137 \\
28.5\end{array}$ & $\begin{array}{r}266 \\
55.3\end{array}$ & $\begin{array}{r}480 \\
100.0\end{array}$ & 4.28 & 1.00 \\
\hline $\begin{array}{l}\text { Producing, processing and packaging } \\
\text { food with geographical indication }\end{array}$ & $\begin{array}{r}14 \\
2.9\end{array}$ & $\begin{array}{r}23 \\
4.8\end{array}$ & $\begin{array}{r}72 \\
15.0\end{array}$ & $\begin{array}{r}164 \\
34.1\end{array}$ & $\begin{array}{r}207 \\
43.0\end{array}$ & $\begin{array}{r}480 \\
100.0\end{array}$ & 4.11 & 1.05 \\
\hline
\end{tabular}

Note: Scale values 1 - Not at all important; 2 - Slightly important; 3 - Neutral; 4 - Important; 5 - Extremely important.

and "viticulture" with an average score of 3.99, respectively. Similar results were obtained from both EU and KOU students. The fact that people attach greater importance to healthy nutrition nowadays has led to an increase in the areas of investment in organic agriculture. This is probably why the students attributed a higher level of importance to this project subject.

The students who want to benefit from the Young Farmer Grant Project are required to invest in agriculture and also live in the rural area. In other words, students will continue their lives in agriculture and rural areas. Students who have no family land will be able to rent. In this study, logistical regression (logit model) was performed for determining the factors that affect the possibility of students to benefit from the Young Farmer Grant Project. In the logit model, the dependent variable is student's willingness to benefit from the Young Farmer Grant Project. The model's independents variables are age, sex, place of birth, place of residence, monthly family income, the situation of being a farmer in the family, having a family-owned farmland and regular job status. As is seen from Table 9, definitions of dependent and independent variables.

Before testing whether the explanatory variables are important in the model, it should be tested whether the model is statistically significant. At this stage, the following hypotheses are created: 
Table 9 - Variables used for logit models.

\begin{tabular}{|c|c|c|}
\hline Dependent variables & \multicolumn{2}{|c|}{ Variable categories } \\
\hline $\begin{array}{l}\text { The student's willingness to benefit from the Young } \\
\text { Farmer Grant Project }\end{array}$ & 1: Yes & \\
\hline \multicolumn{3}{|l|}{ Independent variables } \\
\hline Age (year) & $2: 22-24$ & $3: \geq 25$ \\
\hline Sex & 1: Female 2: Male & \\
\hline Place of birth & $\begin{array}{l}\text { 1: Province center } \\
\text { 3: Town }\end{array}$ & $\begin{array}{l}\text { 2: District center } \\
\text { 4: Village }\end{array}$ \\
\hline Place of residence & $\begin{array}{l}\text { 1: Province center } \\
\text { 3: Town }\end{array}$ & $\begin{array}{l}\text { 2: District center } \\
\text { 4: Village }\end{array}$ \\
\hline Monthly family income & $\begin{array}{l}1: \leq 1500 \text { TRY } \\
3: \geq 2501 \text { TRY }\end{array}$ & 2: 1501-2500 TRY \\
\hline The situation of being a farmer in the family & 1: Yes & \\
\hline Having a family-owned farmland & 1: Yes & \\
\hline Regular job status & $0:$ No & \\
\hline
\end{tabular}

H0: Some variables have no effect on the possibility of benefiting from the project.

$\mathrm{H}_{1}$ : At least one variable has an impact on the possibility of benefiting from the project.

According to the results obtained, the model was found to be significant at $\mathrm{p}<0.01$ level and $\mathrm{H} 0$ hypothesis was rejected.

The aim of the model is to identify factors that affect the likelihood of students benefiting from young farmer grant support. The confirmatory classification rate (CCR) for this model was $78.1 \%$. The use of logit model showed that there is a statistically significant between the dependent and the independent variables $(\mathrm{p}=0.000$, $\mathrm{R}^{2}=0.253$ ). The results of the logit model estimation are shown in Table 10. Accordingly, males are less likely to benefit from young farmer grant support than females. But this information is not a statistically significant $(\mathrm{p}=0.754>0.05)$. For the variables "Age $(\leq 21$ and $\geq 25)$ ", "The situation of being a farmer in the family", "Having a family-owned farmland" and "Regular job status", the relevant Beta coefficients were found to be statistically significant $(p<0.01)$. And "The place of birth (village)" was a statistically significant $(\mathrm{p}<0.05)$. Age, the situation of being a farmer in the family and having a family-owned farmland positively affect the possibility of benefiting from the project.

\section{Discussion and Conclusion}

The agricultural sector is promoted through various policies in all countries of the world. Given the fact that a major part of the population is employed in the agricultural sector in developing countries like Turkey, government support is essential to make the agricultural sector have a steady structure (Dogan et al., 2018). The recent supports given to, and policies developed for, the agricultural sector in Turkey show the importance attached to agricultural production. The share of dynamic youth population in total population is $16.4 \%$. The development of rural youth, then, plays a vital role in preventing agricultural depopulation in the future. However, this is possible only when social and economic opportunities are enhanced in rural areas and rural areas are made desirable for the young people who live in rural areas or live in the city but have the potential of migrating to rural areas.

The European Union has similar problems to Turkey (aging agricultural population, the youth's disengagement from agriculture, etc.). Current evidence has revealed that the number 
Table 10 - Results of logit model.

Dependent variables

The student's willingness to benefit from the Young Farmer Grant Project 1: Yes 0: No

\begin{tabular}{|c|c|c|c|c|c|}
\hline Independent variables & Beta & Std. Error & Wald & $p$ & $\operatorname{Exp} .(ß)$ \\
\hline Sex & 0.078 & 0.249 & 0.098 & 0.754 & 1.081 \\
\hline \multicolumn{6}{|l|}{ Age } \\
\hline$\leq 21$ & 1.478 & 0.204 & 12.881 & $0.002 * *$ & 1.613 \\
\hline $22-24$ & -0.158 & 0.450 & 0.123 & 0.726 & 0.854 \\
\hline$\geq 25$ & 1.668 & 0.472 & 12.505 & $0.000 * *$ & 5.301 \\
\hline \multicolumn{6}{|l|}{ Place of birth } \\
\hline Province center & 0.431 & 1.525 & 0.080 & 0.778 & 1.539 \\
\hline District center & 0.103 & 0.422 & 0.059 & 0.808 & 1.108 \\
\hline Town & -0.105 & 0.427 & 0.061 & 0.806 & 0.900 \\
\hline Village & -1.639 & 0.769 & 4.547 & $0.033^{*}$ & 0.194 \\
\hline \multicolumn{6}{|l|}{ Place of residence } \\
\hline Province center & 0.342 & 0.687 & 0.103 & 0.884 & 1.105 \\
\hline District center & -0.358 & 0.515 & 0.484 & 0.486 & 0.699 \\
\hline Town & -0.262 & 0.583 & 0.202 & 0.653 & 0.770 \\
\hline Village & -0.194 & 0.615 & 0.099 & 0.753 & 0.824 \\
\hline \multicolumn{6}{|l|}{ Monthly family income } \\
\hline$\leq 1500$ TRY & -0.197 & 0.294 & 0.358 & 0.479 & 0.726 \\
\hline 1501-2500 TRY & -0.175 & 0.304 & 0.332 & 0.565 & 0.840 \\
\hline$\geq 2501 \mathrm{TRY}$ & -0.096 & 0.262 & 0.133 & 0.715 & 0.909 \\
\hline The situation of being a farmer in the family & 0.929 & 0.290 & 10.245 & $0.001 * *$ & 2.532 \\
\hline Having a family-owned farmland & 1.026 & 0.258 & 15.832 & $0.000 * *$ & 2.791 \\
\hline Regular job status & -0.948 & 0.374 & 6.419 & $0.011 * *$ & 0.387 \\
\hline Constant & -1.223 & 0.551 & 4.926 & $0.026^{*}$ & 0.294 \\
\hline \multicolumn{2}{|c|}{ Log likelihood-LL: $=459.740 \quad$ Cox \& Snell $\mathrm{R}^{2}=0.172$} & \multicolumn{4}{|c|}{ Nagelkerke $\mathrm{R}^{2}=0.253$} \\
\hline
\end{tabular}

Notes: *It is significant at the 0.05 level; ** It is significant at the 0.01 level.

of young farmers in several developed countries such as the United States and European countries has decreased over the last decades as a consequence of technological, social, and economic changes (Mills-Novoa, 2011; Chen et al., 2014; Mihi-Ramirez and Kumpikaite, 2014; Bednaříková et al., 2016; Leonard et al., 2017; Duesberg et al., 2017; Mishra et al., 2010). The latest European Union Farm Structure Survey indicated that, by 2013, 55.8\% of European farmers were over 55 years of age (Eistrup et al., 2019) and only 8.7\% of farmers in the European Union were younger than 35 years of age (Castillo-Quero and Guerre-
ro-Baena, 2019). The disengagement of the youth from agriculture poses a threat to its long-term sustainability. The youth in Europe disengage from agriculture due to lack of rural infrastructure and many other socio-economic problems. In the European Union, the youth are encouraged to own farm establishments by means of incentives and supports through the Common Agricultural Policy (Unakitan and Başaran, 2018).

In a study conducted in Greece was evaluated the aid programmes for young farmers and, more specifically, the first measure of the third axis of the operational programme "Rural De- 
velopment - Regeneration of the Countryside 2000-2006", based on improvements to the level of viability. The categorical regression was used in this study. The results show that the orientation of the farms, after the implementation of the financing programme, is towards exploiting the comparative advantages of the various regions by making use of suitable crops (Aggelopoulos and Arabatzis, 2010).

Zagata and Sutherland (2015) argued in their study, that there is insufficient evidence to adequately inform debates about the role of young people in European agriculture, proposing a research agenda which includes more consistent conceptualization of the 'young farmer problem', targeted research on the role of young people in agricultural innovations, assessment of regional differences within countries, and identification of farm succession processes in new EU Member States.

As part of the Young Farmer Grant Project, which was put into effect in 2016 in Turkey, 30,745 18-40-year-old people were granted 933 million Turkish Liras between the years 20162017. These figures demonstrate that the youth are willing to invest in agriculture if they are supported and guided. Filloux et al., carried out a study in 2019, on Thai agriculture students of Thailand and found that good results will be obtained from graduate students with agricultural support to be given to young people. Their results support the situation in Turkey.

According to results of this study, most of the agricultural students think themselves knowledgeable about investing in agriculture. Their greatest expectation from the Young Farmer Grant Project is an increase in the number of young people engaged in agriculture in the future, indicating that the youth lean towards investing in agriculture, provided they receive, in addition to agricultural education, government incentives and supports as well as family support.

In Turkey, not only gradual rural depopulation but also the higher average age of people engaged in agriculture pose a threat to the future of agricultural production. The only factor to reverse this trend is the youth. To this end, rural areas must be rendered appealing to the youth by enhancing social and economic opportunities in villages such as education, employment, health care, housing and infrastructure. If income and living conditions are improved in rural areas, the youth will not intend to migrate to the city and agriculture will become attractive for them, which will also play a fundamental role in rural development.

The increased importance of agriculture and nutrition suggests the necessity of raising the awareness of, and guiding, the youth in respect of agricultural production. There is a need for an organization to communicate with the students of agricultural faculties and vocational schools. Those students must be guided by means of detailed information about agricultural investment education, incentives and supports as well as case studies.

The greatest expectations of the students from investing in agriculture are to create employment and implement agricultural innovations, respectively. So, the youth look with favor on investing in agriculture because it provides them with employment opportunities and the chance of managing their own business. Besides, today's youth keep up with the cutting-edge technology and are more interested in the investments that allow them to employ high-tech tools in agriculture. The investment cost of the technologies used in agriculture is quite high. For this reason, increasing the amount of supports and simplifying application requirements will encourage both agricultural students and other investors more.

In this study, the agricultural students were asked the likelihood of making use of the Young Farmer Grant Project support, and $72.5 \%$ of them responded with "likely" and "extremely likely", proving their willingness to invest in agriculture. Thus, agricultural entrepreneurship courses may be offered to students during their period of study for enabling them to design and realize the investing activities they have in mind.

The Young Farmer Grant Project intended for agricultural students and other young people in respect of agricultural investment is a considerable step for Turkey. Today, the con- 
tinuity of agricultural production is critically important. So, social security status, marketing opportunities and higher amounts of support are crucial for encouraging the youth to take advantage of such supports.

Therefore, it is essential to pursue necessary policies to support and guide agricultural students, who hold the future of agriculture.

\section{References}

Aggelopoulos S., Arabatzis G., 2010. European Union young farmers program: A Greek case study. New Medit, 9(2): 50-55.

Ayele S., Khan S., Sumberg J. (eds.), 2017. Africa's youth employment challenge new perspectives. IDS Bulletin Transforming Development Knowledge, 48(3): 1-66.

Bădan D.N., Vasile-Tudor B., Fîntîneru G., 2019. Analysis of the funds allocated to farmers through the measure 112 "setting up of young farmers". In: Soliman K.S. (ed.), Proceedings of $33^{\text {rd }}$ International-Business Information Management Association (IBIMA) Conference (Granada, April 10-11), pp. 7930-7937.

Bournaris Th., Moulogianni Ch., Arampatzis S., Kiomourtzi F., Wascher D.M., Manos B., 2016. A knowledge brokerage approach for assessing the impacts of the setting up young farmers policy measure in Greece. Environmental Impact Assessment Review, 57: 159-166.

Bednaříková Z., Bavorová M., Ponkina E.V., 2016. Migration motivation of agriculturally educated rural youth: The case of Russian Siberia. Journal of Rural Studies, 45: 99-111.

Bierens H.J., 2004. The Logit Model: Estimation, Testing and Interpretation. Department of Economics, The Pennsylvania State University. Available at: http://econ.la.psu.edu / hbierens/ ML_LOGIT. PDF (accessed: 15 November, 2017).

Brodzinski Z., 2019. Trends of the process of modernization of farms managed by young farmers. In: Proceedings of 20th International Scientific Conference on Economic Science for Rural Development (Jelgava-Latvia, April 9-10), pp. 312-319.

Castillo-Quero M., Guerrero-Baena M.D., 2019. Structural, productive and financial characterization of farms run by young farmers. Itea - Información Técnica Económica Agraria, 115(1): 62-82.

Chen R., Ye C., Cai Y., Xing X., Chen Q., 2014. The impact of rural out-migration on land use transition in China: past present and trend. Land Use Policy, 40: 101-110.
Corsi A., 2009. Family farm succession and specific knowledge in Italy. Rivista di Economia Agraria, LXIV(1-2): 13-30.

Cristea A., Bozgă N.A., Tiţa V.D., Munteanu C.C., 2019. Young Romanian farmers' perceptions regarding sustainable agriculture. Proceedings of BASIQ International Conference on New Trends in Sustainable Business and Consumption (Bari, 30 May-1 June), pp. 466-479.

Derderi A., Daoudi A., Colin J.P., 2015. Young itinerant farmers and the development of potato farming in Algeria. The Emergence of a Reticular Economy, Cahiers Agricultures, 24(6): 387-395.

Dogan H.G., Kan A., Kan M., Tosun F., Ucum İ., Solmaz C., 2018. Evaluation of the factors affecting the benefiting level from The Young Farmers Project Support in TR 71 Region of Turkey. Turkish Journal of Agriculture - Food Science and Technology, 6(11): 1599-1606.

Doğan Z., Arslan, S., Berkman A.N., 2015. Development and problems of agricultural sector in Turkey: a historical outlook. Niğde University Academic Review of Economics and Administrative Sciences, 8(1): 29-41.

Doğanay S., Alim M., 2010. A study on concept of city by rural population in Turkey: Yeşilyurt Village (Trabzon). Eastern Geographical, 15(23): 171-184.

Đurić K., Njegovan Z., 2015. Mechanisms of support fort the young rural population in The European Union. Economics of Agriculture, 62(4): 10031016.

Đurić K, Kuzman B., Prodanović R., 2019. Support to young farmers through agricultural policy measures: the experience of the EU and Serbia. Economics of Agriculture, 66(1): 237-249.

Duesberg S., Bogue P., Renwick A., 2017. Retirement farming or sustainable growth - land transfer choices for farmers without a successor. Land Use Policy, 61: 526-535.

Eistrup M., Sanches A.R., Muñoz-Rojas J., Pinto Correia, T., 2019. A "Young farmer problem"? Opportunities and constraints for generational renewal in farm management: An example from Southern Europe. Land, 8(4): 70.

Engindeniz S., Can B.A., 2020. Youth and female employment in the rural part of Turkey. Rural Development, 19: 43-45.

Filloux T., Faysse N., Pintobtang P., 2019. The long road to becoming a farmer: Thai agricultural students' plans. Outlook on Agriculture, 48(4): 273 281.

Greene W.H., 1993. Econometric analysis, $2^{\text {nd }}$ ed. New York, NY: Macmillan Publishing. 775 pp. 
Gujarati D.N., 1995. Basic econometrics, $3^{\text {rd }}$ ed. New York, NY: McGraw Hill. 570 pp.

Harakal'ova L., 2013. Budget of the common agricultural policy of The European Union under the financial framework for the period 2014-2020. In: Proceedings of 14th International Scientific Conference on International Relations: Contemporary Issues of World Economics and Politics, Bratislava, Republic of Slovak, 4, pp. 252-257.

Harakal'ova L. 2014. New form of the common agricultural policy of the European Union after 2014. In: Honová I., Hon M., Melecký L., Staníčková M. (eds.), Proceedings of the 2nd International Conference on European Integration 2014. Ostrava: VŠB - Technical University of Ostrava, pp. 211-218.

Kan M., Tosun F., Kan A., Gokhan Dogan H., Ucum I., Solmaz C., 2019. Young farmers in agriculture sector of Turkey: Young Farmers Support Program. Journal of Agricultural Science \& Technology, 21(1): 15-26.

Leonard B., Kinsella A., O’Donoghue C., Farrell M., Mahon M., 2017. Policy drivers of farm succession and inheritance. Land Use Policy, 61: 147-159.

May D., Arancibia S., Behrendt K., Adams J., 2019. Preventing young farmers from leaving the farm: Investigating the effectiveness of the young farmer payment using a behavioural approach. Land Use Policy, 82: 317-327.

McKillop J., Heanue K., Kinsella J., 2018. Are all young farmers the same? An exploratory analysis of on-farm innovation on dairy and drystock farms in the Republic of Ireland. The Journal of Agricultural Education and Extension, 24(2): 137-151.

Mihi-Ramirez A., Kumpikaite V., 2014. Economics reason of migration from point of view of students. Procedia - Social and Behavioral Sciences, 109: 522-526.

Mills-Novoa M., 2011. Sustaining Family Farming Through Mentoring: A Toolkit for National Family Farm Coalition Members. National Family Farm Coalition, USA.

Mishra A.K., El-Osta H.S., 2016. Determinants of decisions to enter the U.S. Farming sector. Journal of Agricultural and Applied Economics, 48(1): 73-98.

Mishra A.K., El-Osta H.S., Shalik S., 2010. Succession decisions in U.S. family farm businesses. Journal of Agricultural and Resource Economics, 35(1): 133-152.

Mosaee M., Ommani A., 2011. Assessment the socio-economic factors affecting rural youth attitude to occupation in agricultural (Case of Kohgiluyeh and Boyer-Ahmad Province, Iran). International Journal of Agricultural Management and Development, 1(1): 15-19.
Phiboon K., Cochetel C., Faysse N., 2019. Support programmes and the diversity of young farmers in Thailand: A good match? Outlook on Agriculture, 48(4): 300-308.

Ramanathan R., 1995. Introductory econometrics with applications, $3^{\text {rd }}$ ed. New York, NY: Dryden Press. 718 pp.

Salvago M.R., Phiboon K., Faysee N., Lai Nguyen T.P., 2019. Young people's willingness to farm under present and improved conditions in Thailand. Outlook on Agriculture, 48(4): 282-291.

Sav O., Sayin C., 2018. General assessments of main factor affecting tendency to stay in agriculture. Journal of Agriculture and Nature, 21: 190-197.

Šimpach O., 2017. Importance of young farmers in selected member states of European Union. In: Löster T., Langhamrová J., Vrabcová J. (eds.), Proceedings of 10th International Scientific Conference on Reproduction of Human Capital - Mutual Links and Connections (RELIK 2017). Prague: Oeconomica Publishing House, pp. 446-453.

Šimpachová Pechrová M., Šimpach O., 2018. Financial support from EU's Common Agricultural Policy for young farmers in the Czech Republic. In: Staníčková M., Melecký L., Kovářová E., Dvoroková K. (eds.), Proceedings of the 4th International Conference on European Integration 2018. Ostrava: VŠB - Technical University of Ostrava, pp. 1466-1473.

Sottomayor M., Tranter R., Costa L., 2011. Likelihood of succession and farmers' attitudes towards their future behaviour: Evidence from a Survey in Germany, the United Kingdom and Portugal. International Journal of Sociology of Food and Agriculture, 18(2): 121-133.

TOB (Republic of Turkey Ministry of Agriculture and Forestry), 2013. Strategic Plan 2013-2017. https://www.tarimorman.gov.tr/SGB/Belgeler/ Stratejik\%20Plan\%202013-2017.pdf (accessed: 2 November 2019).

Touzeau L., 2019. "Being stewards of land is our legacy": Exploring the lived experiences of young black farmers. Journal of Agriculture, Food Systems, and Community Development, 8(4): 45-60.

TurkStat (Turkish Statistical Institute), 2019. Address Based Population Registration System (ABPRS), City / Town Center, Town / Village Population. http://tuik.gov.tr/PreTablo.do?alt_id=1059 (accessed: 2 November 2019).

TurkStat (Turkish Statistical Institute), 2018. Main Statistics / National Account. http://www.turkstat. gov.tr/UstMenu.do?metod=temelist (accessed: 17 December 2018). 
Unakitan G., Başaran B., 2018. A suggestion for the success of the young farmer project: young farmer cooperatives. Balkan and Near Eastern Journal of Social Sciences, 4(2): 149-157.

Yalçın G.E., Munis T., İpekçioğlu Ş., Birol D., 2020. A Tendency to maintain agriculture of farmers benefiting from the Grant Support of a Young Farmer in Gaziantep and Sanliurfa. Turkish Journal of Agriculture - Food Science and Technology, 8(3): 526-530.
Walters L., Severin J., Ferrier L., 2018. Filling the GAPP: supporting young and women farmers to grow, adopt, produce and profit. Rural Extension and Innovation Systems Journal, 14(1): 110-116. Zagata L., Sutherland L.A., 2015. Deconstructing the 'young farmer problem in Europe': Towards a research agenda. Journal of Rural Studies, 38: $39-51$. 